\title{
Derecho y capitalismo: Una lectura a la luz de Althusser y Pachukanis ${ }^{1}$
}

Law and capitalism: A reading in the light of Althusser and Pachukanis

Direito e capitalismo: uma leitura à luz de Althusser e Pachukanis

Droit et capitalisme: une lecture à la lumière d'Althusser et de Pachukanis

\begin{tabular}{l|l} 
Juliana Paula Magalhães & \\
& $\begin{array}{l}\text { Universidade de São Paulo, } \\
\text { Brasil }\end{array}$
\end{tabular}

Revista Derechos en Acción

Año 3/No 9 Primavera 2018, 290-326

DOI: https://doi.org/10.24215/25251678e222

ORCID: https://orcid.org/

Recibido: 17/09/2018

Recibido con modificaciones: 28/09/2018

Aprobado: 01/11/2018

Resumen: Se trata de un estudio acerca de la intrinseca relación entre derecho y capitalismo -cuyo lastre reside en las proposiciones teóricas de Althusser y Pachukanis. Marx apunta que la característica fundamental de la sociedad capitalista es la constitución de la fuerza de trabajo en mercadería. Él demuestra una ruptura con los modos de produccion anteriores. Althusser, por otro lado, presenta una innovador lectura del pensamiento marxista al propugnar una noción de un corte epistemológico, separando las obras de Marx de juventud de las de madurez. La concepción althusseriana del marxismo busca romper con las visiones ideológicas de carácter humanista, presentando a Marx

1 Traducción de Pablo Octavio Cabral.

2 Doutoranda e mestra em Filosofia e Teoria Geral do Direito pela Faculdade de Direito da Universidade de São Paulo e bacharela em Direito pela mesma instituição. 
como el descubridor de un nuevo continente del conocimiento científico. Pachukanis, a su turno, basándose en las obras de madurez de Marx, apunta que el derecho es la forma estructurante y necesaria del capitalismo, en vista que, en ese modo de producción, es imprescindible que las personas adopten una forma social de subjetividad jurídica, la que no se deriva de la norma sino de la materialidad de las relaciones sociales. Por consiguiente, ante la imbricación entre derecho y capitalismo, se constata la imposibilidad teórica y práctica de un socialismo jurídico.

Palabras clave: Marxismo; derecho; capitalismo; subjetividad jurídica; Althusser; Pachukanis.

Abstract: This is a study of the intrinsic relationship between law and capitalism - whose ballast lies in the theoretical propositions of Althusser and Pachukanis. Marx points out that the fundamental characteristic of capitalist society is the constitution of the labor force in merchandise. He demonstrates a break with previous modes of production. Althusser, on the other hand, presents an innovative reading of Marxist thought by advocating a notion of an epistemological cut, separating Marx's works of youth from those of maturity. The Althusserian conception of Marxism seeks to break with ideological visions of a humanist character, presenting Marx as the discoverer of a new continent of scientific knowledge. Pachunakis, in turn, based on Marx's mature works, points out that law is the structuring and necessary form of capitalism, in view of the fact that, in this mode of production, it is essential for people to adopt a social form of juridical subjectivity, which does not derive from the norm but from the materiality of social relations. Therefore, in the face of the overlap between law and capitalism, the theoretical and practical impossibility of a juridical socialism is confirmed.

Key words: Marxism; Law; Capitalism; Legal Subjectivity; Althusser; Pachukanis.

Resumo: Trata-se de estudo - cujo lastro reside nas proposições teóricas de Althusser e Pachukanis - acerca a intrínseca relação entre direito e capitalismo. Marx aponta que a característica fundamental da sociedade capitalista é a constituição da força de trabalho em mercadoria. Temse assim uma ruptura com os modos de produção anteriores. Althusser apresenta inovadora leitura do pensamento marxista ao propugnar a noção de um corte epistemológico na produção teórica de Marx, 
separando as obras de juventude e de maturidade do pensador alemão. A concepção althusseriana do marxismo busca romper com as visões ideológicas de caráter humanista, apresentando Marx como o descobridor de um novo continente ao conhecimento científico. Pachukanis, a seu turno, embasado nas obras de maturidade de Marx, aponta que 0 direito é forma estruturante e necessária do capitalismo, haja vista que, nesse modo de produção, é imprescindível que as pessoas tomem forma social de subjetividade jurídica, a qual não decorre da norma, porém da materialidade das relações sociais. Por conseguinte, diante da imbricação entre direito e capitalismo, constata-se a impossibilidade teórica e prática de um socialismo jurídico.

Palavras-chave: Marxismo; Direito; Capitalismo; Subjetividade Jurídica; Althusser; Pachukanis.

Résumé: II s'agit d'une étude - dont l'object réside dans les propositions théoriques d'Althusser et de Pachukanis - sur la relation intrinsèque entre le droit et le capitalisme. Marx soutient que la caractéristique fondamentale de la société capitaliste est la conversion de la force de travail en marchandises. II a également une rupture avec les modes de production antérieurs. Althusser présente une lecture innovante de la pensée marxiste, en proposant une notion de coupe épistémologique dans la production théorique de Marx, séparant les œuvres de jeunesse de celles de la maturité du penseur allemand. La conception althussérienne du marxisme cherché una rupture avec les visions idéologiques de caractère humaniste, en présentant Marx comme le découvreur d'un nouveau continent de connaissances scientifiques. Pachunakis, basé sur les travaux de la maturité de Marx, soutient que le droit est la forme structurante et nécessaire du capitalisme, car, dans ce mode de production, il est essentiel que les individus adoptent une forme sociale de subjectivité juridique, laquelle ne se dérive pas de la norme, malgré la matérialité des relations sociales. Par conséquent, en face aux relations du droit et capitalisme, I'impossibilité théorique et pratique d'un socialisme juridique est vérifiée.

Mot-clés: Marxisme; droit, capitalisme; subjectivité juridique, Althusser; Pachukanis. 


\section{Introducción}

La propuesta de nuestro artículo es, en una perspectiva marxista, investigar la estructural imbricación entre derecho y capitalismo a partir de los avances teóricos emprendidos por Louis Althusser y Evguiéni Pachukanis.

El jurista brasileño Alysson Leandro Mascaro presenta una interesante propuesta de lectura del pensamiento jurídico contemporáneo, destacando que él puede ser dividido en tres grandes bloques: iuspositivismo, no iuspositivismo y crítica $^{3}$.

El iuspositivismo, en síntesis, concibe el derecho a partir del marco normativo. El no iuspositivismo ve al derecho como el resultado de relaciones de poder. Por su parte, la crítica, que se presenta como la senda o camino del marxismo, busca develar el fenómeno jurídico a partir de la materialidad de las relaciones sociales de modo de producción capitalista. Althusser y Pachukanis se insertan en este último horizonte.

\section{La lectura althusseriana del marxismo: anti humanismo y crítica de la ideología jurídica}

Louis Althusser, célebre filósofo francés del siglo $\mathrm{XX}^{4}$, presentó una innovadora lectura del pensamiento marxista, cuyo alcance era alejar las concepciones ideológicas del marxismo,

3 MASCARO, Alysson Leandro. Filosofia do direito. 6.ed. São Paulo: Atlas, 2018, p. 310-319.

4 “0 filósofo francês Louis Althusser (1918-1990) propôs uma peculiar leitura do marxismo, conforme veremos mais adiante. 0 pensamento de Louis Althusser está longe de ser unanimidade nos meios marxistas. [...] As polêmicas acerca da leitura althusseriana do marxismo persistem até os dias atuais. Contudo, a importância do pensamento de Althusser pode ser medida pelas palavras de um de seus mais notáveis discípulos, o filósofo francês Étienne Balibar: "Althusser não pertence mais somente à história da 'filosofia marxiana' dos anos 60 e 70, seu lugar, grande ou pequeno, está na história da filosofia". [...] No que se refere ao percurso intelectual de Althusser, em geral, são apontadas, pelo menos, a existência de três fases principais, considerando suas obras mais relevantes. [...] A primeira, na década de 1960, na qual o filósofo desponta para os meios intelectuais internacionais, com obras como Pour Marx e Lire Le Capital. A segunda fase, entre o final dos anos de 1960 e a década de 1970, marcada pela autocrítica e revisão de alguns posicionamentos teóricos. E, por fim, a terceira fase, a partir da década de 1980, na qual ele se dedica especialmente ao chamado 
confiriéndole el status de ciencia ${ }^{5}$. Las contribuciones de Althusser al marxismo son inmensas ${ }^{6}$, bien como a la propia filosofía de modo general.

El Filósofo francés presenta a Karl Marx como el descubridor de un nuevo continente del conocimiento científico ${ }^{7}$, tal como fueron, en sus respectivas áreas, Tales de Mileto, Galileu Galilei, Isaac Newton y Sigmund Freud, por ejemplo ${ }^{8}$. El continente-historia descubierto por Marx representa la ruptura con el humanismo- presente, inclusive, en la propia obra de Marx, en sus textos de juventud- y la construcción de una nueva comprensión teórica acerca de la materialidad de las relaciones sociales?.

Althusser divide la obra de Marx en obras de juventud (18401844), obras de corte (1845), obras de maduración (1845-1857) y obras de madurez $(1857-1883)^{10}$. En esa lectura original de la

\footnotetext{
"materialismo aleatório"." (MAGALHÃES, Juliana Paula. Marxismo, humanismo e direito: Althusser e Garaudy. São Paulo, Ideias \& Letras, 2018).

5 “[...] nous pouvons affirmer que Marx a fondé une nouvelle science : la science de I'histoire des "formations sociales». (ALTHUSSER, Louis. Pour Marx. Paris: La Découverte/Poche, 2005, p. 263).

6 MOTTA, Luiz Eduardo. A favor de Althusser - revolução e ruptura na teoria marxista. Rio de Janeiro: FAPERJ, 2014.

7 "Para Althusser, o marxismo não é um mero guia para a ação e tampouco uma "concepção de mundo". 0 marxismo é uma teoria científica cujas pedras fundamentais foram assentadas por Marx." (BOITO JR., Armando. Indicações para o estudo do marxismo de Althusser. In: PINHEIRO, Jair (Org.). Ler Althusser. Marília: Oficina Universitária; São Paulo: Cultura Acadêmica, 2016, p. 156.).
}

8 ALTHUSSER, Louis. Pour Marx. Paris: La Découverte/Poche, 2005, p. 264.

9 "Althusser explique que Marx em 1845 a "changé de terrain" em changeant de ploblematique (en posant d'autres questions, qui ne sont pas le "renversement" des precedentes, mais constituent une véritable "emérgence"): du terrain idéologique il est passé sur le terrain réel, par la destruction de la problématique illusoire de l'Homme feuerbachien et du Sujet d'histoire, et la formulation d'une problématique des déterminations réels du procès historique (l'infrastructure du mode de production, la superstructure politico-idéologique). Mais se changement de terrain, qui s'effectue immédiatement après le "triomphe de I'humanisme" chez Marx (dans les Ouvres de Jeunesse, singulièrement les "Manuscrits de 44"), a pour contenu essentiel de développement d'une connaissance (objective, scientifique) de l'ideologie." (BALIBAR, Étienne. L'objet d'Althusser. In: LAZARUS, Sylvain. Politique et Philosophie dans I'ouvre de Louis Althusser. Paris: PUF, 1993, p. 88-89).

10 ALTHUSSER, Louis. Pour Marx. Paris: La Découverte/Poche, 2005, p. 27. 
producción intelectual de Marx reside una de las contribuciones fundamentales del pensamiento althusseriano, en la medida en que permite comprender que los textos del Marx maduro se consubstancian en un edificio teórico completamente distinto. El humanismo, que caracterizaba los textos juveniles de Marx, fueron extirpados del núcleo estructurante de sus obras de madurez ${ }^{11}$, a través de un proceso denominado por Althusser de corte epistemológico, siendo que tal denominación dada por el filósofo francés es fruto de la influencia de Gastón Bachelard ${ }^{12}$.

Los Manuscritos de 1844 son un ejemplo contundente de la presencia del humanismo en las construcciones teóricas del joven Marx. Muchos pensadores del marxismo, tales como, por ejemplo, Roger Garaudy, apuntan esa obra como el "acto de nacimiento del marxismo"13. Para Althusser, tal perspectiva presenta un grave error de lectura del marxismo. Althusser entiende que, en ese período, Marx aún no era marxista, ósea, no había aún descubierto una nueva ciencia, más aún estaba trabajando en un horizonte ideológico, preso de conceptos como hombre, sujeto y alienación, que se constituían en obstáculos epistemológicos para el desenvolvimiento científico ${ }^{14}$.

La fundación de la ciencia de la Historia por Marx, la que tiene por objeto las "formas de existencia específica de la especie humana" 15 , en la visión althusseriana, representa una mudanza de problemática, en la cual Marx abandona las nociones

\footnotetext{
11 "La rupture avec toute toute anthropologie ou tout humanisme philosophiques n'est pas un détail secondaire: elle fait un avec la découverte scientifique de MarX» (ALTHUSSER, Louis. Pour Marx. Paris: La Découverte/Poche, 2005, p. 234).

12 Ibid., p. 24.

13 GARAUDY, ROGER. A propos des "manuscrits de 1844" de Marx. In: Cahiers du Communisme, mars, 1963, p. 108.

14 AlTHUSSER, Louis. A querela do humanismo. Crítica Marxista, n. 9. São Paulo: Xamã, 1999, p. 32.

15 “La science de I'histoire n'a pas pour objet l'essence de l'homme, ou du genre humain, ou l'essence des hommes, etc. La science de I'histoire a pour objet l'histoire des formes d'existence spécifiques de l'espèce humaine." (ALTHUSSER, Louis. La querelle de I'humanisme. In: Écrits philosophiques et politiques - Tome II. Paris : Stock/IMEC, 1997, p. 482.)
} 
humanistas, y pasa a trabajar a partir de conceptos teóricos como modos de producción, fuerzas productivas, formas sociales, relaciones de producción, mercancía, valor, entre otros. ${ }^{16}$

Para Althusser, por tanto, el marxismo es un anti-humanismo teórico ${ }^{17}$, en la medida en que la teoría marxista no tiene como núcleo fundante los conceptos de hombre, esencia humana, alienación y sujeto. Eso no significa un deprecio por las condiciones de vida de los hombres, más, por el contrario, la constatación de que para comprender a la sociedad capitalista $\mathrm{y}$, por consiguiente, la realidad social de los individuos, se debe tener en cuenta, primeramente, las estructuras sociales dadas, las cuales producen al sujeto como efecto ideológico, a partir de prácticas materiales específicas ${ }^{18}$. El filósofo francés observa que el humanismo debe ser rechazado, inclusive, en

16 ALTHUSSER, Louis. Polêmica sobre o humanismo. Tradução de Carlos Braga. Lisboa: Presença, 1967, p. 191.

17 "J'ai dit ailleurs, et je répète, qu'en toute rigueur il faudrait parler de l'a-humanisme théorique de Marx. Si j'ai employé l'expression anti-humanisme théorique de Marx (comme je propose également de parler de l'anti-historicisme, de l'anti-évolutionnisme, et anti-structuralisme de la théorie marxiste) c'est pour mettre l'accent sur l'aspect polémique impitoyable de la rupture que Marx dut consommer pour concevoir et énoncer sa découverte. " (ALTHUSSER, Louis. La querelle de I'humanisme. In: Écrits philosophiques et politiques Tome II. Paris : Stock/IMEC, 1997, p. 447).

18 "L'anti-humanisme théorique de Marx dans le matérialisme historique, c'est donc le refus de fonder dans un concept d'homme à prétention théorique, c'est-à dire comme sujet originaire de ses besoins (homo oeconomicus), de ses pensées (homo rationalis), de ses actes et de ses luttes (homo moralis, juridicus et politicus) l'explications de formations sociales et de leur histoire. Car quand on part de l'homme, on ne peut éviter la tentation idéaliste de la toute-puissance de la liberté ou du travail créateur, c'est-à-dire on ne fait rien que subir, en toute " liberté ", la toute-puissance de l'idéologie bourgeoise dominante, qui a pour fonction de masquer et d'imposer, sous les espèces illusoires de la libre puissance de l'homme, une autre puissance, autrement réelle et puissante, celle du capitalisme. Si Marx ne part pas de I'homme, s'il refuse d'engendrer théoriquement la societé et l'histoire à partir du concept de l'homme, c'est pour rompre avec cette mistification qui n'exprime qu'un rapport de force idéologique, fondé dans le rapport de production capitaliste. Marx part donc de la cause structurale qui produit cet effet idéologique bourgeoise qui entretient l'illusion qu'on devrait partir de l'homme: Marx part de la formation économique donnée, en l'espèce, dans Le Capital, du rapport de production capitaliste, et des rapports qu'il détermine en dernière instance dans la superestructure. [...] Si Marx ne part donc pas de l'homme qui est une idée vide, c'est-à-dire surchargée d'idéologie bourgeoise, c'est pour arriver aux hommes concrets 
el plano político, pues los discursos atravesados por esa forma ideológica terminan por debilitar las luchas por una transformación social ${ }^{19}$, en la medida en que enmascaran la lucha de clases ${ }^{20}$. Él también se contrapone a las lecturas economicistas del marxismo, las cuales pregonan la primacía de las fuerzas productivas sobre las relaciones de producción y desembocan en una visión teleológica de la historia ${ }^{21}$. Tales lecturas llegan a creer que el desenvolvimiento de las fuerzas productivas, por sí solo, podría llevar al socialismo ${ }^{22}$.

La cuestión del humanismo en el marxismo fue objeto de discusiones candentes en diversos ámbitos, tanto académicos como políticos. En ese contexto, podemos destacar el debate ocurrido en el Partido Comunista Francés, en la década de 1960,

[...] .» (ALTHUSSER, Louis. Soutenance d'Amiens. In: Positions. Paris: Editions Sociales, 1976, p. 170-171).

19 "Quand on dit aux prolétaires "ce sont les hommes qui font l'histoire", il n'est pas besoin d'être grand pour compreendre qu'à plus ou moins longue écheance contribue à les désorienter et à les désarmer. On leur fait croire qu'ils sont tout-puissants comme "hommes", alors qu'ils sont desarmes comme prolétaires en face de la véritable toute-puissance, celle de la bourgeoise qui détient les conditions matérielles (les moyens de production) et politiques (I'Etat) qui commandent I'histoire. [...] Quando on leur chante la chanson humaniste, on les détourne de la lutte de classes, on les empêche de se donner et d'exercer la seule puissance dont ils disposent: celle de l'organisation en classe, et de l'organisation de classe, les syndicats et le Parti, pour conduire leur lutte de classe à eux." (ALTHUSSER, Louis. Réponse a John Lewis. François Maspero, 1973, p. 48-49).

20 "Althusser rattache précisément la possibilité d'agir sur l'idéologie, à partir de sa connaissance, de mettre en oeuvre une véritable "politique idéologique" qui serait aussi politique de transformation de l'ideologie (rejouant em quelque sorte à l'infini le passage historique de la politique humaniste à la politique de la lutte des classes, de "Tout les hommes sont frères" à "Prolétaires de tout les pays, unissez-vous!")." (BALIBAR, Étienne. L'objet d'Althusser. In: LAZARUS, Sylvain. Politique et Philosophie dans I'ouvre de Louis Althusser. Paris: PUF, 1993, p. 94)

21 TURCHETTO, Maria. As características específicas da transição ao comunismo. Tradução de Márcio Bilharinho Naves. In: NAVES, Márcio Bilharinho (Org.). Análise Marxista e Sociedade de Transição. Campinas: UNICAMP, 2005, p. 7.

22 "O privilegiamento das forças produtivas obscurece o papel da luta de classes nas formações sociais e implica necessariamente o reforço da figura do homem, do sujeito, enquanto produtor de coisas, de objetos. (NAVES, Márcio Bilharinho. Marx - Ciência e Revolução. São Paulo: Quartier Latin, 2008, p. 64) 
con el protagonismo de Roger Garaudy y de Louis Althusser, en lados opuestos. En mi libro Marxismo, humanismo y derecho: Althusser y Garaudy, recientemente publicado en Brasil por la Editorial Ideias \& Letras, trato con profundidad ese importante debate -que transciende las fronteras del partido y adquiere escala mundial- y de sus impactos para la comprensión del fenómeno jurídico.

Para muchos marxistas, inclusive para Garaudy, al vaciarse el marxismo de su carácter humanista, se transforma al hombre en "un títere llevado al escenario por las estructuras"23. La atribución de la "pecha" de estructuralista sobre la lectura althusseriana del marxismo es bastante común. Entendemos que Althusser no puede ser clasificado como un filósofo estructuralista -rótulo que él rechazaba- ${ }^{24}$, aunque haya sufrido la influencia de esta corriente filosófica, habida cuenta de que la concepción estructural presente en el pensamiento althusseriano se deriva de sus lecturas de las propias obras de Marx.

Althusser apunta que, en el capitalismo, la sociedad se caracteriza como un todo complejo estructurado, compuesto de instancias que se relacionan ininterrumpidamente, de modo que la interacción entre esos niveles se da de manera compleja ${ }^{25}$. En esa estructura, inciden simultáneamente determinaciones diversas, en un proceso de sobredeterminación, aunque la determinación por la economía se dé en última instancia ${ }^{26}$.

En la visión del filósofo francés, no hay un sujeto de la historia, siendo completamente absurda la idea de que los hombres hacen la historia. En la realidad, la historia es un

23 GARAUDY, Roger. Apelo aos vivos. Tradução de H.P. de Andrade. Rio de Janeiro: Nova Fronteira, 1981, p. 54.

24 ALTHUSSER, Louis. Éléments d'autocritique. Paris: Librairie Hachette, 1974, p. 64.

25 Id. Sobre a Revolução Cultural. Tradução de Márcio Bilharinho Naves. In: NAVES, Márcio Bilharinho (Org.). Presença de Althusser. Campinas: Instituto de Filosofia e Ciências Humanas, 2010, p. 165.

26 Id.. Pour Marx. Paris: La Découverte/Poche, 2005, p. 87-116. 
proceso sin sujeto ni fin, cuyo motor es la lucha de clases $^{27}$. Por tanto, Althusser rompe con todas las lecturas subjetivistas y teleológicas del marxismo y destaca la importancia de analizar los movimientos históricos a partir de la concreción de las relaciones sociales.

Es importante destacar que Althusser no niega la actuación humana en el proceso histórico, sin embargo, el destaca que eso se hace a partir de determinaciones oriundas del marco estructural constituido a partir de la materialidad de cada tiempo histórico, de modo que la historia no es hecha por el individuo o por el sujeto, sino por las masas ${ }^{28}$.

Siendo así, la subjetividad es vista por el filósofo francés como un efecto ideológico debido a una causa estructural, de manera que, en la sociedad capitalista, el sujeto que en ella se presenta es producto típico de ese modo de producción. En ese contexto, la ideología jurídica se presenta como la ideología por excelencia del capitalismo, en vista que la figura del sujeto de derecho es indispensable para la propia reproducción de capital ${ }^{29}$.

La lectura althusseriana de la ideología es concebida con interesante originalidad, a partir de una conjugación entre

27 ALTHUSSER, Louis. Remarque sur une catégorie: procès sans Sujet ni Fin (s). In: Réponse a John Lewis. Paris : François Maspero, 1973, p. 69-76.

28 "Partir de l'homme et la liberte humaine, en exaltant l'action des hommes sur l'histoire, et leur possibilite de dépasser leur condition, c'est en effet oublier les bases matérialistes du marxisme. [...] ce n'est pas I'homme, mais les "masses". [...] Mais nous dit Althusser cela ne suffit pas. Dire cela, c'est encore être dans l'idéologie, car dire ce qui est premier, ce sont les masses, c'est faire des masses un sujet. [...] Le procès de l'histoire est um procès sans sujet [...] I'histoire n'a pas de sujet, pas de commencement, mais um "moteur": la lutte de classes [...] et pas seulement les classes. Car ce qui est moteur, n'est moteur que par le mouvement, et le mouvement, c'est la contradiction. Ce qui est donc premier est un rapport contradictoire, et non pas um sujet." (THÉVENIN, Nicole-Edith. Révisionnisme et philosophie de l'aliénation. Paris: Christian Bourgois, 1977, p. 236).

29 "Il suffit de simple manuels de droit ou de jurisprudence, pour voir à ciel ouvert que le Droit, qui, cas unique, fait un avec son idéologie, car il a besoin d'elle pour pouvoir " fonctionner ", donc l'idéologie juridique est, en dernière instance et, le plus souvent, sous des formes d'une suprenante transparence, la base de toute l'idéologie bourgeoise. " (ALTHUSSER, Louis. Éléments d'autocritique. Paris: Librairie Hachette, 1974, p. 36-37). 
marxismo y psicoanálisis ${ }^{30}$. Así, para el filósofo francés, la ideología es constituida a través de la materialidad de las relaciones sociales y opera en el inconsciente, por lo que no se trata de una mera opción. El sujeto, en esa perspectiva, es visto como un constructo ideológico originado de prácticas materiales reiteradas. Pronto, Althusser entiende que el "sujeto consciente de sî" es una concepción eminentemente burguesa, destituida de carácter científico ${ }^{31}$.

Althusser también traza una contribución fundamental al pensamiento marxista al presentar el concepto de aparatos ideológicos del Estado, los que actúan predominantemente en el ámbito ideológico, ramificados en las esferas religiosa, escolar, familiar, política, sindical, de información, cultural, jurídica, entre otras. Tales aparatos son distintos, por lo tanto, los aparatos represivos del Estado, lo que comprenden las instituciones de carácter represivo y operan especialmente por medio de la represión, de modo que en ellos la ideología ocupa un papel residual. Los aparatos ideológicos del Estado tienen correspondencia con las diferentes organizaciones, tales como las iglesias, las escuelas, los medios de comunicación masivos, los sindicatos, los partidos políticos, también como con las instituciones políticas y jurídicas ${ }^{32}$.

Los aparatos ideológicos del Estado tienen sus actuaciones pautadas por prácticas materiales efectivas, siendo constituyentes y constituidos por relaciones sociales concretas, de modo que la constitución subjetiva, en la sociedad capitalista,

30 «A aproximação operada por Althusser entre marxismo e psicanálise consiste antes de tudo na constatação de uma dupla negação, reiterada repetidas vezes em sua obra: Freud rejeitou o mito do homo psychologicus, assim como Marx, com a crítica da economia política clássica, dissolveu o mito do homo oeconomicus." (GILLOT, Pascale. Althusser e a Psicanálise. Tradução de Pedro Eduardo Zini Davoglio (Org.); Fábio Ramos Barbosa Filho; Marie-Lou Lery-Lachaume. São Paulo: Ideias \& Letras, 2018, p. 25).

31 ALTHUSSER, Louis. Freud e Lacan. Marx e Freud. Tradução de Walter José Evangelista. Rio de Janeiro: Graal, 1991, p. 84.

32 ALTHUSSER, Louis. Idéologie et appareils idéologiques d'État. In: Positions. Paris: Editions Sociales, 1976, p. 67-125. 
necesariamente para por ellos. Los referidos aparatos son indispensables para la reproducción capitalista, pues "constituyen subjetividades intrínsecamente sumergidas en la lógica del mercado" 33 .

Derecho y Estado operan por medio de la representación estatal cuanto por medio de la ideología jurídica, la que está en la base de la ideología burguesa, en la medida en que ella se funda en la subjetividad jurídica, que oblitera la visión acerca de la realidad de la lucha de clases $^{34}$. El mecanismo de interpelación ideológica que constituye los sujetos de derechos, lo cuales de muestran dotados de los atributos de libertad e igualdad, es fundamental para la perpetuación del capitalismo, pues permite la compra y la venta de la fuerza de trabajo en el mercado. A partir de ahí, se puede percibir que la postulación humanista de que todos los hombres son libre e iguales por naturaleza está íntimamente ligada a la ideología jurídica, encontrando terreno fértil para desenvolverse justamente en el período histórico de ascenso económico y político de la burguesía, en vista que la ideología está dotada de materialidad, o sea, surge a partir de las prácticas materiales concretas.

La ideología jurídica está necesariamente imbricada en el humanismo, pronto, la postulación de un humanismo marxista representa una visión con ausencia de cientificidad, por no ser atingente a la comprensión de los meandros de reproducción capitalista, intermediando, inclusive, en la posibilidad de ruptura con ese modo de producción ${ }^{35}$.

\footnotetext{
33 MASCARO, Alysson Leandro. Estado e forma política. São Paulo: Boitempo, 2013, p. 127.

34 "La ideología jurídica "prueba» que el orden social no reposa sobre la existencia de clases, sino precisamente sobre la de los individuos a los que el derecho se dirige". (BALIBAR, Étienne. Sobre la dictadura del proletariado. Madrid: Siglo XXI, 1977, p. 45)
}

35 “0 socialismo, na leitura de Althusser, é um termo científico. Seu pleito se dá a partir de bases concretas contra a sociabilidade do capital. Já o humanismo, mesmo um humanismo socialista, é um termo ideológico. Ele está embalado em conceitos do Marx juvenil, como alienação e reificação. Se se toma por fundamento essa leitura marxista da juventude, o homem deve ser libertado de suas amarras e reinvestido à sua condição plena, uma espécie de humanismo real. Contra tal humanismo que carreia um arrefecimento das lutas 
En las obras de juventud de Marx, especialmente en los Manuscritos de 1844, la categoría de propiedad privada ocupaba un papel central, de forma que su concepción de comunismo se estructuraba meramente en la noción de repartición, presentándose, por tanto, sometida a las nociones de ideología jurídica ${ }^{36}$. El humanismo, consustanciado con el concepto de alienación, se hacía presente, ocasionando una postura teórica que no se desapegaba del par "sujeto/objeto" y, por consiguiente, permitía que se pudiese pensar en el derecho como instrumento para que los hombres lograsen la recuperación de su esencia ${ }^{37}$.

Siendo así, la constatación althusseriana de que el marxismo se constituye en un anti-humanismo teórico trae impactos profundos para la comprensión del derecho en el capitalismo, en la medida en que demuestra el cambio de problemática en las obras de Marx, despegándose, por tanto, de la ideología jurídica presente en sus textos de juventud. La concepción humanista del marxismo es calcada de la noción de subjetividad, luego, no permite que se proceda a la crítica estructural de la categoría sujeto de derecho. ${ }^{38}$

sociais, porque se situa no núcleo do indivíduo como base do mundo, Althusser insiste num anti-humanismo teórico. [...] 0 marxismo, ao tratar cientificamente do socialismo, não parte da categoria homem, mas, sim, de todo o ferramental de conceitos como mercadoria, valor, forma social, produção, classe etc. Com isso, não se quer dizer que o anti-humanismo teórico seja contra o homem, mas, sim que até mesmo para a perspectiva de uma sociabilidade mais humanitária é preciso beber das fontes da ciência da transformação social e não de chaves teóricas pré-marxistas, como o indivíduo." (MASCARO, Alysson Leandro. Filosofia do direito. 6. ed. São Paulo: Atlas, 2018.

36 THÉVENIN, Nicole-Edith. Révisionnisme et philosophie de l'aliénation. Paris: Christian Bourgois, 1977, p. 92-96.

37 "Nos Manuscritos de 44, toda a problemática da alienação se "resolve" em um simples ato jurídico: a supressão da alienação decorreria da extinção da propriedade privada. 0 homem poderia então recuperar sua essência perdida nos objetos que produz, e que thes "escapam", porque eles não são mais a propriedade dele próprio, mas de um outro, estranho a ele e a ele sobreposto, e que deles se apropria. 0 direito devolveria ao homem o tecido roto de sua "generalidade", de sua verdadeira condição humana." (NAVES, Márcio Bilharinho. A Questão do Direito em Marx. São Paulo: Outras Expressões; Dobra, 2014, p. 93)

38 MAGALHÃES, Juliana Paula. 0 direito no debate marxista sobre o humanismo. In: Marxismo, humanismo e direito: Althusser e Garaudy. São Paulo: Ideias \& Letras, 2018, p. 169-212. 
En la perspectiva althusseriana, no hay teleología, luego, la llegada al comunismo no se presenta como fatalidad o como finalidad histórica inexorable, de modo que la transición socialista es vista como un proceso de ruptura con las estructuras sociales burguesas, por medio de una acción revolucionaria de masas, que podrá o no ocurrir dependiendo de desarrollo de los movimientos históricos. Por lo tanto, la propia dialéctica, en Althusser, es pensada de manera distinta de aquella tradicionalmente asentada en los medios marxistas de inspiración hegeliana, pues ella no es vista como mera "negación de la negación", más sí como ruptura ${ }^{39}$. En sus últimos textos, Althusser tomó su lectura anti-teleológica de los procesos históricos al límite, al teorizar sobre el materialismo aleatorio, que, entre otras posibilidades de lectura, puede ser entendido como una teoría de transición entro los modos de producción ${ }^{40}$.

Así, se verifica que el pensamiento de Louis Althusser es indispensable para la comprensión del marxismo, especialmente por presentar una innovadora lectura de corte epistemológico de la producción teórica de Marx, bien para traer luz indispensable sobre el problema de la ideología, ampliando los horizontes del marxismo, a partir de una conjugación con el psicoanálisis. Sin embargo, aunque ha alcanzado elevada comprensión de la ideología jurídica y de su importancia para la reproducción capitalista, en relación con el derecho propiamente dicho, Althusser tiene un abordaje, en cierta medida, limitado ${ }^{41}$. Así, para la

39 ALTHUSSER, Louis. Por Marx. Tradução de LOUREIRO, Maria Leonor F.R. Campinas: UNICAMP, 2015, p. 85.

40 "[...] o que é um modo de produção? Dissemos, seguindo Marx: uma "combinação" particular de elementos. [...] Esses elementos não existem na história para que exista um modo de produção, eles existem em estado "flutuante" antes de sua "acumulação" e "combinação", sendo cada um o produto de sua própria história e não o produto teleológico dos outros ou da história deles." (ALTHUSSER, Louis. A corrente subterrânea do materialismo do encontro. Tradução de Mónica G. Zoppi Fontana. Disponível em:

$<$ https://www.ifch.unicamp.br/criticamarxista/arquivos_biblioteca/artigo110artigo1.pdf>. Acesso em: 07 jul. 2017, p. 32-33.)

41 "Por menos ambiciosa que seja sua teorização a respeito do direito, temos que ela é capaz de forjar uma problemática geral no interior da qual o direito poderia ser encarado nos 
elucidación plena de la especificidad histórica del derecho y su imbricación en el modo de producción capitalista, precisaremos recorrer los notables avances teóricos emprendidos por el jurista ruso Evguiéni Pachukanis.

\section{Pachukanis y la forma jurídica}

Evguiéni Pachukanis puede ser considerado el principal pensador del derecho en el campo del marxismo por introducir una innovadora lectura del fenómeno jurídico a partir de la obra madurez de Marx $^{42}$. El jurista ruso, haciendo uso del método marxista, emprende una relectura del derecho, demostrando su intrínseca ligazón con el capitalismo rompiendo con la tradicional visión juspositivista ${ }^{43}$. Teoría general del derecho y marxismo, su obra más importante, presenta una crítica contundente a la teoría general del derecho tradicionalmente asentada, subvirtiendo sus bases al desvelar el "secreto" de la forma jurídica, con lastre en las herramientas teóricas ofrecidas por el marxismo. En ese sentido, observa Márcio Bilharinho Naves,

seus diversos níveis de abstração, bem como nas diversas funções que é obrigado a assumir na conformação e reprodução do modo de produção capitalista, o que o poria em posição de um ponto de partida útil para um enfrentamento crítico do direito como ideal abstrato e como conjunto de práticas." (DAVOGLIO, Pedro. Althusser e o direito. São Paulo: Ideias \& Letras, 2018, p. 208).

42 “O jurista russo Evguiéni Pachukanis (1891-1937) é o maior pensador do direito do marxismo. Sua expressividade se deve ao mergulho profundo que empreendeu para extrair, da lógica do próprio Marx - em especial nas suas obras de maturidade, como em 0 Capital -, uma teoria do direito, compreendendo sua especificidade e sua íntima conexão com o capital." (MASCARO, Alysson Leandro. Filosofia do direito. 6. ed. São Paulo: Atlas, 2018, p. 472).

43 “Não se devem tomar as relações capitalistas como um bloco genérico para que fique clara, então, a verdade do direito. Tampouco o direito pode ser entendido de maneira abstrata, fora da história específica das próprias relações capitalistas. 0 direito é imediatamente verificado quando, pelas primeiras vezes, estrutura-se um sistema de trocas mercantis generalizadas. 0 fundamento metodológico de Pachukanis, portanto, demonstra-se fiel ao próprio Marx. A forma jurídica não é tomada como um mero normativismo genérico, fora da história. É a circulação mercantil que dá especificidade ao direito. Logo, a forma jurídica é um dado histórico-social concreto, do plano do ser e não mais do dever-ser, como o foi com toda a tradição metafísica e juspositivista." (MASCARO, Alysson Leandro. Filosofia do direito. 6. ed. São Paulo: Atlas, 2018, p. 476). 
en los principales estudios del pensamiento pachukaniano en la actualidad: "la concepción de Pachukanis corresponde enteramente a las reflexiones que Marx desarrolla, sobre todo en Grundrisse o en $O$ capital, a propósito del lugar central que ocupa el análisis de la forma para comprender las relaciones sociales capitalistas" 44 .

La radicalidad de las ideas pachukanianas, no obstante, la notoriedad alcanzada por el jurista ruso en la entonces Unión de Repúblicas Socialistas Soviéticas, acabó originando persecuciones por parte del régimen stalinista, que culminaron con su muerte precoz. La crítica de Pachukanis al derecho, del cual postulaba la imposibilidad de un socialismo jurídica, iba a contramano de las prácticas soviéticas en aquel período ${ }^{45}$.

Pachukanis se distancia completamente del positivismo jurídico, que postula una identificación entre derecho y norma. Para el, el derecho es forma social ${ }^{46}$ inherente al modo de producción capitalista ${ }^{47}$, cuyo núcleo reside en el sujeto de derecho,

44 NAVES, Márcio Bilharinho. Marxismo e direito: um estudo sobre Pachukanis. São Paulo: Boitempo, 2013, p. 48.

45 "0 que Pachukanis fez foi uma verdadeira "revolução copernicana" no âmbito do direito, subvertendo completamente o modo de se compreender esse fenômeno, para além de todas as "evidências" e "certezas" consolidadas por séculos de elaboração jurisprudencial. É dele 0 mérito teórico e histórico de ter buscado, acompanhando as indicações de Marx, especialmente em 0 Capital, a natureza íntima do direito no processo do valor de troca, portanto, o mérito de ter captado a sua especificidade burguesa. A extrema radicalidade teórica e política que decorre desse enunciado basilar, ao implicar na única crítica consequente ao normativismo e na completa interdição de qualquer espécie de "socialismo jurídico", até mesmo as que se encobriam sob as enganosas vestes de um direito "popular", "proletário" ou "socialista", elevou Pachukanis ao posto de maior influência no front jurídico soviético, mas também foi responsável pelo seu rápido declínio, que culminaria com a sua trágica e prematura morte." (KASHIURA JR., Celso Naoto; NAVES, Márcio Bilharinho. Pachukanis e a Teoria Geral do Direito e o Marxismo. Revista Jurídica Direito \& Realidade, v. 1, n. 2 (2011). Disponível em: www. fucamp.edu.br/editora/index.php/direito-realidade/article/view/245. Acesso em: 16 nov. 2018.

46 "Se se assemelhar forma à fôrma que pode ser preenchida por conteúdos variados, a transposição de tal perspectiva ao plano social dirá respeito aos moldes que constituem e configuram os sujeitos, atos e suas relações." (MASCARO, Alysson Leandro. Estado e forma política. São Paulo: Boitempo, 2013, p. 21).

47 "A teoria marxista encara qualquer forma social como histórica". (PACHUKANIS, Evguiéni. Teoria Geral do Direito e Marxismo. Tradução de Paula Vaz de Almeida. São Paulo: Boitempo, 
de manera que el momento normativo, resultado del sello estatal, ocurre apenas posteriormente. Así, el derecho se presenta como producto de las prácticas materiales de carácter capitalista, las que se constituyen a partir de la forma mercantil. Es interesante destacar las propias palabras de Pachukanis acerca de esta cuestión:

(...) la dogmática jurídica concluye que todos los elementos existentes en la relación jurídica, entre ellos el propio sujeto, son generados por la norma. En verdad, claro, la condición previa fundamental por medio de la cual todas las normas concretas ganan significado consiste en la existencia de la economía mercantil monetaria. Apenas mediante esa condición previa el sujeto de derecho tiene susubstrato material en la persona del sujeto económico egoísta, que la ley no crea, más encuentra delante de sí y determina. Así, donde ese substrato está ausente, la relación jurídica correspondiente es a priori inconcebible (...) El poder estatal confiere claridad y estabilidad a la estructura jurídica, pero no crea sus presupuestos, los cuales están arraigados en las relaciones materiales, o sea, de producción. ${ }^{48}$

Piotr Stutchka, célebre jurista contemporáneo a Pachukanis, también traza un camino de apartamiento en relación al juspositivismo $^{49} \mathrm{y}$, a partir de una perspectiva marxista, identifica el derecho como "expresión directa de la lucha de clases"

2017, p. 119).

48 PACHUKANIS, Evguiéni. Teoria Geral do Direito e Marxismo. Tradução de Paula Vaz de Almeida. São Paulo: Boitempo, 2017, p. 103-104.

49 “Evguiéni Pachukanis não funda sua leitura do direito diretamente nas instituições normativas, afastando, assim, o juspositivismo recorrente da autoexplicação dos juristas. Mas também não se situa no patamar intermediário das explicações do direito pelo poder. Esse campo vasto e altamente constratante entre seus pensadores vai de um Carl Schmitt a um Michel Foucault e, insolitamente, congrega boa parte do pensamento jurídico da esquerda - daquela de um direito insurgente ou alternativo - e também do próprio marxismo - como é o caso de Piotr Stutchka." (MASCARO, Alysson Leandro. Política e crise do capitalismo atual: aportes teóricos. In: Crise e Golpe. São Paulo: Boitempo, 2018, p. 108).

50 MASCARO, Alysson Leandro. Filosofia do direito. 6. ed. São Paulo: Atlas, 2018, p. 467. 
Pachukanis reconoce la verdad parcial de la proposición de Stutchka, sin embargo, no se limita a ella, pues busca desentrañar el corazón del derecho burgués ${ }^{51}$, utilizando el mismo método que Marx utilizó para hacer una crítica a la economía política.

Marx demuestra que el capitalismo se caracteriza por la universalización de la forma mercantil, que se deriva de la mercantilización de la fuerza de trabajo ${ }^{52}$. En ese contexto, se constituye la forma jurídica, en la medida en que para que los cambios de mercancías capitalistas pueden ocurrir, es necesario que tanto proletarios como capitalistas se conviertan en sujetos de derecho libres e iguales. Luego, la subjetividad jurídica es oriunda de las relaciones de producción capitalistas ${ }^{53}$.

51 "O camarada P. I. Stutchka, a nosso ver, colocou de modo muito acertado o problema do direito como sendo um problema das relações sociais. Mas, em vez de começar a buscar objetividades sociais específicas, voltou-se para a definição formal habitual, ainda que limitada por questões de classe. Segundo a fórmula geral elaborada pelo camarada Stutchka, o direito já não mais figura como uma relação social específica, mas como o conjunto das relações em geral, como um sistema de relações que corresponde aos interesses da classe dominante e os assegura pelo uso da força organizada. Como consequência, no interior desses sistemas de classes, o direito como relação é indistinguível das relações sociais em geral, e o camarada Stutchka já não está em condições de responder à capciosa questão do professor Reisner sobre como as relações sociais se transformam em instituições jurídicas ou como o direito se transformou no que é. [...] A definição dada pelo camarada Stutchka, talvez por ser produto do Comissariado do Povo para a Justiça, está ajustada às necessidades da prática jurídica. Ela demonstra as limitações empíricas que a histórica sempre coloca à lógica jurídica, mas não expõe as raízes profundas dessa mesma lógica. Essa definição revela o conteúdo de classe contido nas formas jurídicas, mas não nos explica por que esse conteúdo assume tal forma." (PACHUKANIS, Evguiéni. Teoria Geral do Direito e Marxismo. Tradução de Paula Vaz de Almeida. São Paulo: Boitempo, 2017, p. 96).

52 “0 que caracteriza a sociedade capitalista é, portanto, que a força de trabalho assume para o próprio trabalhador a forma de uma mercadoria que the pertence, razão pela qual seu trabalho assume a forma do trabalho assalariado. Por outro lado, apenas a partir desse momento universaliza-se a forma-mercadoria dos produtos do trabalho." (MARX. Karl. 0 Capital. Tradução de Rubens Enderle. São Paulo: Boitempo Editorial, 2013, p. 245).

53 “[...] a força de trabalho só pode aparecer como mercadoria no mercado na medida em que é colocada à venda ou é vendida pelo seu próprio possuidor, pela pessoa da qual ela é a força de trabalho. Para vendê-la como mercadoria, seu possuidor tem de poder dispor dela, portanto, ser o livre proprietário de sua capacidade de trabalho, de sua pessoa. Ele e o possuidor de dinheiro se encontram no mercado e estabelecem uma relação mútua como iguais possuidores de mercadorias, com a única diferença de que um é comprador e o outro, 
La exploración del trabajo en el capitalismo sólo es posible por medio de la constitución de individuos en sujetos de derecho, pues, caso contrario -si los individuos se presentan destituidos de los atributos de libertad e igualdad-, no se constituiría el contrato de trabajo, que se consubstancia en la compra de fuerza de trabajo del trabajador por parte del propietario de los medios de producción a cambio del salario, en una relación que conlleva la generación de más valor ${ }^{54}$. Por tanto, se verifica que el lastre de la teoría pachukaniana reside en la esfera de producción y no en la mera circulación simple, en vista que la forma jurídica apenas surge cuando las relaciones de producción se tornan capitalistas ${ }^{55}$.

vendedor, sendo ambos, portanto, pessoas juridicamente iguais." (MARX. Karl. 0 Capital. Tradução de Rubens Enderle. São Paulo: Boitempo Editorial, 2013, p. p. 242).

54 "A força de trabalho é a própria capacidade do trabalhador, ou seja, o que o trabalhador aliena ao capitalista no contrato de trabalho é a utilização de suas forças vitais, no processo de produção, durante um intervalo de tempo determinado. Trata-se, então, de uma mercadoria peculiar porque, antes de tudo, a força de trabalho é, em certo sentido, 0 próprio trabalhador: ao alienar um tempo determinado de utilização da sua força de trabalho, o trabalhador aliena um tempo determinado de utilização de suas próprias forças corpóreas e intelectuais. Trata-se, mais ainda, de uma mercadoria peculiar porque a força de trabalho contém em si a especificidade de, uma vez consumida, isto é, posta em movimento no processo de produção propriamente dito, gerar uma quantidade de valor superior àquela dispendida como seu equivalente a título de salário: essa diferença (mais-valor) é apropriada pelo detentor dos meios de produção, o capitalista. [...] 0 trabalhador é, portanto, constituído sujeito de direito na medida em que figura como guardião da mercadoria força de trabalho, 0 que significa dizer: na medida em que figura como guardião de si mesmo como mercadoria." (KASHIURA JR., Celso Naoto. Sujeito de direito e interpelação ideológica: considerações sobre a ideologia jurídica a partir de Pachukanis e Althusser. Revista Direito e Práxis - vol. 6, n. 10. Rio de Janeiro: UERJ, 2015, p. 55)

55 “É verdade que há, para Pachukanis, uma relação de determinação imediata entre forma jurídica e forma da mercadoria, como vimos, mas a determinação em Pachukanis é, a rigor, uma sobredeterminação. A esfera da circulação, que determina diretamente as formas do direito, é por sua vez determinada pela esfera da produção, no sentido preciso de que só o específico processo de organização capitalista do trabalho permite a produção de mercadorias como tais, isto é, como resultado de um trabalho que se limita a ser puro dispêndio de energia laborativa indiferenciada. Ora, se a forma do direito depende da forma da mercadoria, e esta só se realiza no modo de produção capitalista, então a forma jurídica também depende do modo específico de organização do processo do trabalho decorrente da instauração das relações de produção capitalistas. Podemos, então, dizer que, se o direito 
Así, a partir de la constatación del carácter histórico de las formas sociales, se tiene que la forma jurídica deriva directamente de las formas mercantiles, las que constituyen el núcleo estructural del capitalismo ${ }^{56}$. A su vez, la forma jurídica permite la reproducción capitalista, situación que revela un proceso continuo de mutua imbricación, en vista que "el trabajador asalariado surge en el mercado como un libre poseedor de su fuerza de trabajo porque la relación capitalista de explotación es mediada por la forma jurídica del contrato ${ }^{57}$.

En las sociedades pre capitalistas, la forma de subjetividad jurídica estaba ausente, de la misma manera que la forma mercantil, de la cual ella deriva. Aun cuando se admita la existencia de tales formas en el período anterior al advenimiento del capitalismo, puede reconocérselas, como máximo, en carácter incidental y embrionario. Solamente el modo de producción capitalista conlleva la constitución de las formas sociales a el inherentes y peculiares, considerando la ruptura estructural que representó con los modos de producción que le antecedieron.

En la antigüedad, el esclavismo se pautaba por una relación de mando directo entre señor y esclavo, en la cual el vínculo entre ellos se daba por medio de la fuerza. Intercambio de mercancías podían existir entre los señores de esclavos, en tanto, ellos no eran determinantes en aquel modo de producción, en vista que las relaciones de producción eran esclavistas. Por consiguiente, los esclavos eran desprovistos de subjetividad jurídica, por tanto, no se podía de ninguna manera hablar de existencia de una forma jurídica plena. Siendo así, el denominado "derecho

\footnotetext{
"acompanha" o movimento da circulação, uma vez que esse movimento é "comandado" pelas "exigências" da produção, o direito sofre também a determinação dessa esfera, ainda que não de modo imediato." (NAVES, Márcio Bilharinho. Marxismo e Direito - Um estudo sobre Pachukanis. São Paulo: Boitempo, 2013, p. 72-73)

56 "A sociedade capitalista é antes de tudo uma sociedade de proprietários de mercadorias." (PACHUKANIS, Evguiéni. Teoria Geral do Direito e Marxismo. Tradução de Paula Vaz de Almeida. São Paulo: Boitempo, 2017, p. 119)

57 PACHUKANIS, Evguiéni. Teoria Geral do Direito e Marxismo. Tradução de Paula Vaz de Almeida. São Paulo: Boitempo, 2017, p. 118.
} 
romano" es completamente distinto de aquello que se llama derecho en las sociedades capitalistas ${ }^{58}$.

En la edad medida, caracterizada por el modo de producción feudal, también "estaba ausente el concepto abstracto de sujeto de derecho" "59. En aquel período histórico, la dominación que el señor feudal ejercía sobre el siervo se daba de manera directa, siendo que la servidumbre era el vínculo que los unía. El siervo estaba preso de la tierra y de ella dependía para su propia subsistencia y, por otro lado, el señor feudal detentaba el poder político y económico en su feudo, en condición de poseedor de grandes extensiones de tierras. Aquella formación social se caracterizaba por su carácter estamental y, por lo tanto, los conceptos de libertad e igualdad universales estaban ausentes.

Así, conforme observa Pachukanis, "apenas con el completo desenvolvimiento de las relaciones burguesas el derecho adquirió un carácter abstracto"60. La profundización de la forma mercantil conlleva la universalización de la forma jurídica, de modo que los individuos adquieren la predicación de sujetos de derecho, permitiendo que el circuito de intercambio de mercancías se perpetúe $^{61}$. El trabajador pasa a poder vender su fuerza de trabajo en el mercado y al mismo tiempo queda apartado de los medios

58 "A diferença fundamental reside em que a subjetividade no mundo antigo está presa a determinações qualitativas, ela difere de um homem a outro, colocando-os em posições sociais distintas, de sorte que a capacidade volitiva possui graus variados de expressão." (NAVES, Márcio Bilharinho. A questão do direito em Marx. São Paulo: Outras Expressões; Dobra, 2014, p. 71)

59 PACHUKANIS, Evguiéni. Teoria Geral do Direito e Marxismo. Tradução de Paula Vaz de Almeida. São Paulo: Boitempo, 2017, p. 126.

60 Ibid., p. 127

61 "As categorias mais características do direito burguês - 0 sujeito de direito, a propriedade, o contrato etc. - antes de mais nada e mais claramente do que tudo, revelam a sua base material no fenômeno da troca. A categoria do sujeito de direito corresponde à categoria do valor-trabalho. Os atributos da mercadoria, impessoalidade, generalidade e mensurabilidade, são completados pelos atributos formais da igualdade e da liberdade, os quais os proprietários das mercadorias conferem uns aos outros." (PACHUKANIS, Evgeni. A teoria marxista do direito e a construção do socialismo. In: NAVES, Márcio Bilharinho (Org). 0 discreto charme do direito burguês: ensaios sobre Pachukanis. Campinas: IFCH-UNICAMP, 2009, p. 142-143). 
de producción, los que son propiedad de la clase burguesa. Así, los atributos de libertad e igualdad inherentes a la subjetividad jurídica, paradójicamente, pasan a ser integrantes de la estructura de grilletes que construyen la explotación en el capitalismo, el cual se torna posible por medio del contrato y no más por el uso directo de la fuerza como en las sociedades pre capitalistas ${ }^{62}$.

En lo que atañe al Estado, Pachukanis lo conceptúa como forma política inherente al modo de producción capitalista y, tal como la forma jurídica, igualmente derivado de la forma mercantil. A diferencia de los modos de producción anteriores, es recién en el capitalismo que se presenta la forma política estatal, consubstanciándose el Estado en un ente tercero, apartado de las clases, que por sus formas es apto para garantiza la reproducción del capital, pues para que pueda haber la explotación del trabajo por medio del contrato es indispensable que exista una instancia distinta tanto de los propietarios de la fuerza de trabajo como de los propietarios de los medios de producción ${ }^{63}$.

62 "Ainda que o indivíduo A sinta necessidade da mercadoria do indivíduo B, não se apodera dela pela força, nem vice-versa, mas reconhecem-se mutuamente como proprietários, como pessoas cuja vontade impregna suas mercadorias. Em decorrência, aqui entra de imediato 0 momento jurídico da pessoa e da liberdade, na medida em que está contida na primeira. Nenhum deles se apodera da propriedade do outro pela força. Cada um a cede voluntariamente.. [...] Pelo próprio ato da troca, o indivíduo, cada um dos indivíduos, está refletido em si mesmo como sujeito exclusivo e dominante (determinante) do ato da troca. Com isso, portanto, está posta a completa liberdade do indivíduo: transação voluntária; nenhuma violência de parte a parte [...]. Se, portanto, a forma econômica, a troca, põe a igualdade dos sujeitos em todos os sentidos, o conteúdo, a matéria, tanto individual como objetiva, que impele à troca, põe a liberdade. Igualdade e liberdade, por conseguinte, não apenas são respeitadas na troca baseada em valores de troca, mas a troca de valores de troca é a base produtiva, real, de toda igualdade e liberdade. Como ideias puras, são simples expressões idealizadas dessa base; quando desenvolvidas em relações jurídicas, políticas e sociais, são apenas essa base em uma outra potência. E isso também se verifica historicamente. A igualdade e a liberdade nessa extensão são exatamente o oposto da liberdade e igualdade antigas, que não têm justamente 0 valor de troca desenvolvido como fundamento, mas se extinguem com seu desenvolvimento. Elas pressupõem relações de produção que ainda não haviam se realizado no mundo antigo nem tampouco na Idade Média." (MARX, Karl. Grundrisse. Tradução de Mario Duayer e Nélio Schneider. São Paulo: Boitempo, 2011, p. 187-188).

63 “Na medida em que a relação de exploração se realiza formalmente como uma relação entre dois proprietários de mercadoria "independentes" e "iguais", dos quais um, o proletário, 
La lectura materialista emprendida por Pachukanis desmitifica la visión tradicional asentada en que el Estado se constituye en una instancia neutra ${ }^{64}$. El jurista ruso demuestra que el Estado es forma política del capitalismo, ósea, el Estado es capitalista por su forma. La burguesía, en el modo de producción capitalista, no ejerce un dominio directo en relación al proletariado, mas ejerce su explotación por medio de formas sociales, entre la que está el Estado. El Estado está atravesado por la lucha de clases, más no es ella la que determina su estructura.

El avance teórico emprendido por Pachukanis es norma tanto como pensamiento jurídico, en general, cuanto en el propio horizonte marxista, influenciando teóricos posteriores, como, por ejemplo, en el campo del derivacionismo ${ }^{65}$. Pachukanis identifica la especificidad histórica de la forma jurídica, cuyo núcleo reside en la subjetividad jurídica, presentándose como equivalente y reflejo de la forma mercantil. Más allá de eso, el jurista ruso también avanza en el análisis del papel del Estado, presentándolo como forma política del capitalismo y, tal como la forma jurídica, derivada de la forma mercantil. Ese salto cualitativo permite que se logra una comprensión estructural de los papeles del derecho y del Estado en la sociedad capitalista. En esa perspectiva, la norma jurídica no representa la verdad del derecho, ya que la forma jurídica es un producto social. Siendo así, resta evidencia la oposición de la lectura de matriz pachukaniana, en relación con las visiones juspositivistas, conforme explica Alysson Leandro Mascaro, al tratar el debate sobre la derivación del Estado:

\footnotetext{
vende a força de trabalho, e outro, o capitalista, compra-a, o poder político da classe pode adquirir a forma do poder público." (PACHUKANIS, Evguiéni. Teoria Geral do Direito e Marxismo. Tradução de Paula Vaz de Almeida. São Paulo: Boitempo, 2017, p. 144)

64 "O Estado jurídico é uma miragem totalmente conveniente para a burguesia, pois substitui a ideologia religiosa em decomposição e esconde das massas o domínio da burguesia." (PACHUKANIS, Evguiéni. Teoria Geral do Direito e Marxismo. Tradução de Paula Vaz de Almeida. São Paulo: Boitempo, 2017, p. 148)

65 CALDAS, Camilo Onoda. A teoria da derivação do Estado e do direito. São Paulo: Outras Expressões; Dobra, 2015.
} 
El entendimiento de la forma política estatal como derivada de la forma mercantil se empareja con la más radical tradición marxista de comprensión del derecho, que tiene en Pachukanis su punto nodal. El mismo proceso de derivación se da entre la forma de subjetividad jurídica y la forma mercantil. En tal materialidad fundante de las formas sociales, se aleja de las lecturas idealistas -Estado como bien común, derecho como justicia u orden- de tal suerte que queda patente la naturaleza capitalista de la forma política estatal y del derecho. Derivadas de una misma determinación social por la mercancía, forma política estatal y forma de subjetividad jurídica no se confunden. Ni el Estado crea al derecho, ni viceversa, contrastando con los juspositivistas. La subjetividad jurídica es materialmente derivación de la circulación de personas y bienes en el capitalismo. El Estado se erige como relación social notable de la propia valorización del valor. Entre forma política estatal $\mathrm{y}$ forma de subjetividad jurídica, sin embargo, se pasa a un proceso de acoplamiento, ajuste y acomodamiento. Derivadas de la misma dinámica social y de sus formas determinantes, tales formas sociales tienen a implicase posteriormente. ${ }^{66}$

Por lo tanto, como fruto del pensamiento de Pachukanis, queda prohibida la posibilidad de un socialismo jurídico, ante el hecho de que la forma jurídica está necesariamente vinculada a las relaciones capitalistas de producción. Del mismo modo, considerando también la forma política estatal como directamente derivada de la forma mercantil, se tiene por evidenciada la inviabilidad de la perpetuación del Estado en la transición socialista. Siendo así, en la óptica pachukaniana, el socialismo representa un proceso de ruptura con las formas sociales burguesas y, por consiguiente, de extinción del Estado y del derecho.

66 MASCARO, Alysson Leandro. Filosofia do direito. 6. ed. São Paulo: Atlas, 2018, p. 593-594. 


\section{Derecho, Estado y capitalismo}

Althusser y Pachukanis, si bien por medio de abordajes distintos, demuestran que la subjetividad jurídica es peculiar al modo de producción capitalista ${ }^{67}$. En la esclavitud de la antigüedad y en el feudalismo medieval, la figura del sujeto de derecho no se hacía presente en la materialidad de las relaciones sociales. Incluso a nivel filosófico, conforme apunta el jurista francés Michel Villey, en otra clave teórica, la génesis de la subjetividad jurídica ${ }^{68}$, aunque pueda ser encontrada en los escritos de Guillermo de Ockham, apenas se desarrolla en un período posterior, principalmente a partir de la obra de pensadores como Thomas Hobbes, Immanuel Kant, entre otros ${ }^{69}$.

La génesis material de la subjetividad jurídica resulta de la mercantilización de la fuerza de trabajo. En la sociedad capitalista surge y se universaliza la forma mercantil, ocasionando un proceso de derivación de formas sociales. El derecho y el Estado apenas existen sobre el ejido del capitalismo. Aunque muchos se valgan del aforismo ubi societas ibi jus para apuntar una continuidad histórica del derecho -que sería inherente a toda especia de sociedad, desde la antigüedad-, en realidad, el derecho, concebido como forma jurídica nucleada en la figura del sujeto de derecho, tiene historicidad relativamente reciente, cuando se considera todo el período de existencia humana

67 "Althusser e Pachukanis apresentam proposições convergentes no sentido de que 0 direito burguês é produto das relações sociais concretas, ou seja, adveio das necessidades intrínsecas ao capitalismo, sendo, portanto, a ele inerente e peculiar. No entanto, a distinção de abordagem teórica de cada um deles aparece no fato de que, enquanto o foco de Althusser é o estudo profundo e original da ideologia jurídica, em Pachukanis, apresenta-se o desvendar da forma jurídica. Daí a importância de uma abordagem conjugada de ambos os pensadores, de modo a se poder extrair uma compreensão mais acurada do fenômeno jurídico." (MAGALHÃES, Juliana Paula. Marxismo, humanismo e direito: Althusser e Garaudy. São Paulo: Ideias \& Letras, 2018.)

680 pensamento de Michel Villey acerca da questão da subjetividade jurídica é o objeto de minhas pesquisas atuais para a redação de minha tese de doutorado, intitulada "Michel Villey e a subjetividade jurídica", que se encontra em fase de elaboração.

69 VILLEY, Michel. Philosophie du droit. Définitions et fins du droit. Le moyens du droit. Paris: Dalloz, 2001, p. 106-109. 
en la tierra. De la misma manera, el Estado burgués es completamente diverso de los núcleos de poder existente en las sociedades antiguas y feudales.

La imbricación entre derecho, Estado y capitalismo es estructural, en la medida en que la subjetividad jurídica es fundamental para la reproducción capitalista, del mismo modo que la forma política estatal. En la sociedad capitalista, el trabajador se presenta como propietario de su fuerza de trabajo y apto para venderla en el mercado a los propietarios de los medios de producción, de manera libre, por medio del contrato. En esa relación jurídica oriunda de la mercantilización de la fuerza de trabajo, libertad e igualdad son atributos intrínsecos tanto al trabajador cuanto al capitalista, siendo, por tanto, ambos constituidos sujetos de derecho. En el mismo contexto, se presenta la necesidad de una instancia separada tanto de la clase trabajadora, cuanto de la clase burguesa, de modo de permitir que ese proceso se perpetúe. Allí se explicita la derivación de las formas jurídica y política estatal a partir de la forma mercantil. Acerca de ese punto, es importante destacar las aclaraciones de Alysson Leandro Mascaro, en su obra Estado y forma política, considerada una de las más importantes sobre el tema en la actualidad:

El vínculo entre forma política y forma jurídica es de conformación, realizando entre si una especie de derivación de segundo grado, a partir de un fondo primero y necesario que es derivado directamente de la forma mercantil. Y el aparato estatal ya necesariamente existente en las formas jurídica ya anunciadas socialmente se encuentran para entonces establecer un complejo fenoménico político-jurídico. Se puede entender, entonces, que las formas política y jurídica, ambas singulares, son derivadas de formas sociales comunes y apenas posteriormente conformadas, recíprocamente. En tal proceso de conformación, los límites nucleares de las dos formas son necesariamente mantenidos en su especificidad como estructuras fundamentales de reproducción del capital. ${ }^{70}$

70 MASCARO, Alysson Leandro. Estado e forma política. São Paulo: Boitempo, 2013, p. 41. 
El derecho, como como se presenta en la actualidad, es una exclusividad del capitalismo, en vista de "su vínculo con el proceso de subsunción real del trabajo al capital que da el modo de producción capitalista y su carácter específicamente capitalista"71. Eso ocurre, pues, "como la subsunción real del trabajo al capital, el primero se generaliza, y el trabajador se abstrae de sus propias condiciones para entonces vender un dispendio genérico de energía" 72 . En ese contexto, la referida "equivalencia entre trabajadores que se venden conlleva al sujeto de derecho como forma social general"73. Por lo tanto, el derecho, en el capitalismo puede ser definido como "la forma de equivalencia autónoma", luego, "toda relación en que la equivalencia no existe o se encuentra en posición subordinada, es una relación de naturaleza no jurídica, una relación de poder" 74 .

En ese sentido, Pachukanis destaca que "toda relación jurídica es una relación entre sujeto", siendo que "el sujeto es el átomo de la teoría jurídica, el elemento más simple e indivisible, que no puede ser descompuesto" 75 . Por su parte, Althusser, al hacer la crítica al humanismo y a la ideología jurídica en el imbricada, afirma que "el hombre sujeto libre, o el hombre libre sujeto de sus actos y pensamiento, es de inicio un hombre libre para poseer, vender y comprar, al sujeto de derecho"76. Luego, conforme afirma Bernard Edelman, " la marcha de las

71 NAVES, Márcio Bilharinho. A Questão do Direito em Marx. São Paulo: Outras Expressões; Dobra, 2014, p. 79.

72 MASCARO, Alysson Leandro. Política e crise do capitalismo atual: aportes teóricos. In: Crise e golpe. São Paulo: Boitempo, 2018, p. 109.

73 Ibid., p. 109.

74 NAVES, Márcio Bilharinho. A Questão do Direito em Marx. São Paulo: Outras Expressões; Dobra, 2014, p. 87.

75 PACHUKANIS, Evguiéni. Teoria Geral do Direito e Marxismo. Tradução de Paula Vaz de Almeida. São Paulo: Boitempo, 2017, p. 118.

76 ALTHUSSER, Louis. Sustentação de tese em Amiens. Tradução de Rita Lima. In: Posições

1: Rio de Janeiro: Graal, 1978, p. 160. 
fuerzas productivas capitalistas se realiza concretamente en ese lugar, el del sujeto de derecho"77. El jurista francés continúa:

Puedo responder entonces a la pregunta abierta por Althusser: si es verdad que toda la ideología interpelan a los individuos como sujetos, o contenido concreto/ ideológico de la interpelación burguesa y lo siguiente: el individuo es interpelado como encarnación de las determinaciones de valor que intercambia. Y puedo agregar que el sujeto de derecho constituye la forma privilegiada de esta interpelación, en la exacta medida en que el Derecho asegura y asume la eficacia de la circulación ${ }^{78}$.

Por lo tanto, el aspecto central para la comprensión del derecho en el capitalismo es el estudio de la subjetividad jurídica, tanto en su aspecto de forma social cuanto de constructo ideológico. Siendo así, "de algún modo, la reflexión de Althusser al respecto de la subjetividad y se su especificidad en el capitalismo se presta al encuentro con la cuestión pachukanian de la subjetividad jurídica"79.

La subjetividad jurídica está constituida a partir de la materialidad de las relaciones de producción capitalista y, al mismo tiempo, permite que ese modo de producción, estructurado en la explotación, se pueda perpetuar ${ }^{80}$. Así, reviste propiedad la constatación de Alysson Leandro Mascaro: "insisto siempre en

\footnotetext{
77 EDELMAN, Bernard. O Direito Captado pela Fotografia - Elementos para uma teoria marxista do direito. Tradução de Soveral Martins e Pires de Carvalho. Coimbra: Centelha, 1976, p. 66.

78 Ibid., p. 137.

79 MASCARO, Alysson Leandro. Política e crise do capitalismo atual: aportes teóricos. In: Crise e golpe. São Paulo: Boitempo, 2018, p. 111.

80 "O capitalista explora o trabalhador valendo-se do artifício de que este, formalmente, trabalha para aquele porque quis, isto é, porque assinou um contrato de trabalho. Ou seja, 0 vínculo da exploração advém de um instrumento jurídico. 0 trabalho só passa a ser vendido pelo trabalhador por absoluta necessidade, na medida em que ele é afastado dos meios de produção, mas, formalmente, isso se compreende mediante 0 artifício jurídico do uso de sua própria vontade. Nascendo as atividades mercantis capitalistas, nascem em conjunto as instituições jurídicas que lhes dão amparo." (MASCARO, Alysson Leandro. Introdução ao Estudo do Direito. 5. ed. São Paulo: Atlas, 2015, p. 5)
} 
proponer que el sujeto de derecho es tan sólo y apenas otro modo de decir sujeto por el derecho"81.

Así como el derecho tiene su especificidad en las relaciones de producción capitalista, tenemos también, en ese modo de producción, el carácter peculiar del Estado, en cuanto forma política derivada de la forma mercantil, tal como la forma jurídica. La materialización de tales formas sociales es producto de un proceso histórico complejo y conflictivo ${ }^{82}$. Acerca de la constitución de la forma política estatal, es importante destacar las aclaraciones de Mascaro:

Cuando los intercambios se generalizan e incluso el trabajo pasa a ser objeto de intercambio -trabajo asalariado-, los individuos, ante el mercado, apagando sus características de clase, de cultura y de condición económica, reduciéndose a regiones formalmente iguales cambiadas libremente -con el dispositivo de autonomía de la voluntad, se tornan sujetos de derecho. La forma-valor, que permea las relaciones de circulación y producción, está hasta entonces derivada en forma jurídica. Mas la forma-valor sólo puede existir cuando también se deriva en forma política estatal. En el capitalismo, los aparatos que garantizan el vínculo contractual y que XXX contratante y contratado son distintos formalmente de ambas partes. El contrato exprime la forma-valor y el valor es referenciado en cosas, bienes, dinero, propiedad privada. El aparato político, tercero respecto de todos los poseedores y trabajadores, garante, más allá de los vínculos de intercambio y alguno de sus términos, la propia apropiación formal del valor para el sujeto, ósea, la propiedad privada. (...) Así, es el mismo circuito de las relaciones sociales de producción aquel

81 MASCARO, Alysson Leandro. Apresentação. Revista Margem Esquerda, n. 30. São Paulo: Boitempo, 2018, p. 30.

82 "0 capitalismo e o Estado moderno surgiram no curso de um complexo processo histórico, e seu desenvolvimento foi condicionado reciprocamente." (HIRSCH, Joachim. Teoria Materialista do Estado. Tradução de Luciano Cavini Matorano. Rio de Janeiro: Revan, 2010, p. 61). 
que conlleva la forma-valor, la forma-jurídica y la forma política estatal ${ }^{83}$.

Así, podemos observar que la lectura marxista del fenómeno jurídico es totalmente opuesta tanto al idealismo juspositivista cuanto al jusnaturalismo moderno. Derecho y Estado son formas sociales engendradas a partir de la concreción de las relaciones sociales capitalistas, luego, no se constituyen en un a priori de razón, a los moldes kantianos. La célebre oposición entre ser y deber ser, en lo que se refiere al estudio del derecho, es nada más que una construcción ideológica burguesas.

La ideología jurídica desempeña un papel vital para la estructura capitalista, que posee diversos desdoblamientos. La propia concepción que los individuos tienen de sí mismos como dotados de derechos subjetivos, pertenecientes a una patria y a una nación y portadores de ciudadanía es fruto del proceso de interpelación ideológica y constitución subjetiva que se opera de modo inconsciente, a partir de la reiteración de determinadas prácticas materiales, conforme explica Mascaro:

La ideología se deriva de la práctica. No es una deliberación, no está a nivel de capricho o de la voluntad; es el resultado de las relaciones sociales que se cristalizan en formas sociales. La ideología del derecho y del Estado corresponde a la materialidad de las prácticas capitalistas, siendo apenas otro ángulo de éstas. Todos realizan transacciones y cambian parar explotar y ser explotados. La ideología es la del sujeto de derecho. Todos intercambian y reconocen que sus bienes y los bienes ajenos no pueden existir sustentados por la fuerza bruta de cada cual. La ideología es del Estado como única fuerza legítima. Todos se reconocen como ciudadanos y portadores del derecho de elegir sus gobernantes. La ideología es la de la democracia como valor universal. (...) En ese cuadro, la ideología de derecho es el resultado de la materialidad de las relaciones sociales capitalistas. Los valores centrales del derecho no desatan de lo que es la

83 MASCARO, Alysson Leando. Estado e forma política. São Paulo: Boitempo, 2013, p. 26. 
propia concreción de la sociedad de la mercancía. Tanto el derecho es núcleo decisivo y general de la ideología del capitalismo que, ante la crítica al derecho, casi siempre, termina por ser su alabanza. El combate al derecho se da, por regla general, en la reposición de la ideología en su pedestal ${ }^{84}$.

Ante la sofisticación del proceso de constitución subjetiva de los individuos en el capitalismo, explica la dificultad teórica y práctica de pensar y actuar de modo de romper con las estructuras sociales burguesas que se basan en la explotación. En ese contexto, vislumbrar una sociedad futura que no sea erigida a partir de la forma mercantil es un inmenso desafío. Sin embargo, a partir de los avances teóricos emprendidos por Althusser y Pachukanis, enmarcados en un horizonte marxista, es posible, por lo menos, constatar que no será por medio del derecho ni del Estado que se dará ruptura con el modo de producción capitalista.

Por tanto, el socialismo, en cuanto período de transición entre el capitalismo y el comunismo, no puede representar un refuerzo de las formas sociales burguesas, más debe crear las condiciones necesarias para que ellas se extingan. Hablar de "un derecho socialista en una contradicción en sus propios términos" 85 , del mismo modo que concebir un modelo de Estado socialista ${ }^{86}$. Las transformaciones sociales necesarias para que se rompan los grillos de la explotación capitalista no pasan por esas dos esferas. Hay que subrayar que nos e trata

84 MASCARO, Alysson Leandro. A propósito da situação jurídica atual. In: Crise e golpe. São Paulo: Boitempo, 2018, p. 159.

85 MASCARO, Alysson Leandro. Filosofia do Direito. 6. ed. São Paulo: Atlas, 2018, p. 481.

86 “0 Estado é um modo de articulação social insigne do capitalismo, organizando a política a partir de um campo institucional terceiro em face da miríade dos agentes sociais em concorrência. A política antes do capitalismo, por ser de mando direto de senhores feudais ou de escravo, não adquire tal forma social terceira. 0 mesmo há de se dizer do socialismo, que, ao não se estabelecer pela valorização do valor e pela forma-mercadoria, desconheceria a forma política estatal que lhe seria derivada. A política estatal é forma típica e inexorável de uma articulação da produção e das demandas sociais do capital." (MASCARO, Alysson Leandro. Filosofia do Direito. 6. ed. São Paulo: Atlas, 2018, p. 592.) 
de un corte abrupto que destruirá la estructura capitalista, más de un proceso histórico, cuya duración no se puede prever, por el cual se dará un debilitamiento progresivo de tales formas.

Retomando el pensamiento de Althusser, es importante destacar que la llegada al socialismo no dependerá de la actuación de un sujeto, más podrá ser desencadenada por la acción revolucionaria de las masas. También no se trata de una teleología, más de algo que está en el terreno de lo posible. En ese sentido, los decires del filósofo francés:

"Nada garantizará jamás que la realidad del acto consumado de la garantía de su perennidad (...) La historia no es más que la abrogación de un hecho consumado por otro hecho indescifrable a consumarse, sin que se sepa anticipadamente ni en donde, ni cómo el acontecimiento y sus abrogaciones se producirán. Simplemente llegará un día en que las cartas sean redistribuidas y los dados sean lanzados nuevamente sobre la mesa vacía" ${ }^{\prime 7}$.

No obstante, las amplias posibilidades que se abren en el desarrollo del proceso histórico, el hecho de que derecho y Estado, en cuanto formas sociales capitalistas, no sobrevivirán al fin de ese modo de producción.

\section{Conclusión}

En nuestro breve artículo, buscamos trazar un panorama general acerca del papel del derecho en el capitalismo, a partir de las obras de Louis Althusser y Evguiéni Pachukanis. Ambos pensadores trabajan en una perspectiva marxista y vienen a elucidar los mecanismos por los cuales el capitalismo se estructura, bien como las posibilidades de ruptura con ese modo de producción, con base en marco teórico previsto por el marxismo.

Althusser presenta una propuesta de lectura bastante original y fecunda de la producción teórica de Karl Marx, presentando

\footnotetext{
87 ALTHUSSER, Louis. A corrente subterrânea do materialismo do encontro. Tradução de Mónica G. Zoppi Fontana. Disponível em: <https://www.ifch.unicamp.br/criticamarxista/ arquivos_biblioteca/artig0110artig01.pdf>. Acesso em: 07 jul. 2017, p. 14.
} 
la noción de corte epistemológico en la producción intelectual del pensador alemán, dividiendo sus obras de juventud, obras de corte, obras de maduración y obras de madurez. Ahora el filósofo francés fija en 1845 el momento de la referida cesura, reconociendo que tal se dio mediante un proceso de gradual abandono del terreno ideológico hasta el descubrimiento de un nuevo continente al conocimiento científico, continente- Historia.

Las obras de juventud de Marx estaban marcadas por el humanismo y por la ideología jurídica, al paso que las obras de maduración se caracterizan por su cientificidad, trabajando a partir de conceptos específicos, tales como, modos de producción, fuerzas productivas, relaciones de producción, formas sociales, mercancía, valor, entre otros.

Los impactos del descubrimiento científico de Marx son inmensos y desbordan en diversos aspectos, siendo fundamental, inclusive, para la comprensión del fenómeno jurídico en la sociedad capitalista. Al desprenderse de los obstáculos epistemológicos presentes en sus obras de juventud, Marx posibilita una crítica radical del capitalismo y, por consiguiente, del derecho.

Althusser traza innovadores abordajes en lo que hace a la ideología a través de una conjugación entre marxismo y psicoanálisis, demostrando que la operación ideológica se da en el inconsciente. El filósofo francés destaca que, en el capitalismo, la ideología es estructuralmente jurídica, constituyendo a los individuos en sujetos de derecho, dotados de los atributos de libertad e igualdad.

Pachukanis, por su parte, desarrolla una exacta comprensión del derecho en el capitalismo, identifican como forma jurídica inherente a ese modo de producción, contraponiéndose así a las tradicionales visiones juspositivitas. El jurista ruso apunta la subjetividad jurídica como el núcleo de la forma jurídica y directamente derivada de la forma mercantil. Eso se da, pues solamente cuando la fuerza de trabajo se torna mercancía y se universaliza esa forma social, se tiene por constituido a los individuos como sujetos de derecho. El demuestra que, en el 
capitalismo, la explotación no ocurre por medio de la fuerza, más si por medio del derecho. Por lo tanto, el derecho burgués es completamente distinto de aquello que se llama derecho en las sociedades pre capitalistas, ya que en aquellas sociedades estaba ausente la "forma de equivalencia subjetiva autónoma", tal como observa Márcio Bilharinho Naves.

En la concepción pachukaniana, derecho y Estado son capitalistas por sus respectivas formas. Así como el derecho, en cuanto forma jurídica, deriva de la forma mercantil, del mismo modo se con el Estado, en cuanto forma política. Para que las relaciones de producción capitalista se puedan perpetrar, es necesario que se presente un tercer ente, apartado de las clases, de ahí el surgimiento de la forma política estatal. Conforme enseña Alysson Leandro Mascaro, forma jurídica y forma política estatal pasan por un proceso de derivación secundaria.

Aunque Althusser no tenía avanzado, como Pachukanis, el estudio de las formas sociales, la lectura althusseriana del marxismo parte una fructífera conjugación con el pensamiento del jurista ruso, ya que Pachukanis, para develar los secretos de la forma jurídica, tiene como base la producción teórica del Marx maduro. Más allá de eso, los descubrimientos de Althusser sobre la ideología jurídica son fundamentales para la comprensión del fenómeno jurídico en el capitalismo.

Así, ante la inexorable imbricación entre derecho, Estado y capitalismo, tiene la imposibilidad teórica y práctica de un socialismo jurídico o de un Estado socialista. Más allá que esas formas sociales subsistan en el período de transición al comunismo, ellas deberán caminar hacia su extinción, como consecuencia del proceso de ruptura con la forma mercantil, que caracteriza a las relaciones de producción capitalistas.

\section{Bibliografía}

ALTHUSSER, Louis (2005). Pour Marx. Paris: La Découverte/Poche. - (2005). Por Marx. Tradução de LOUREIRO, Maria Leonor F.R. Campinas: Unicamp. 
- (1974). Élements d'autocritique. Paris: Hachette.

- (1991) Freud e Lacan. Marx e Freud. Tradução de Walter José Evangelista. Rio de Janeiro: Graal.

- (1967) Polêmica sobre o humanismo. Tradução de Carlos Braga. Lisboa: Presença.

- (1973). Réponse a John Lewis. François Maspero.

- (1997). La querelle de l'humanisme. In: Écrits philosophiques et politiques - Tome II. Paris : Stock/IMEC.

- (1999). A querela do humanismo. Crítica Marxista, n. 9. São Paulo, Xamã.

- (1976). Soutenance d'Amiens. In: Positions. Paris: Editions Sociales.

- (2010). Sobre a Revolução Cultural. Tradução de Márcio Bilharinho Naves. In: NAVES, Márcio Bilharinho (Org.). Presença de Althusser. Campinas: Instituto de Filosofia e Ciências Humanas.

- (1976). Idéologie et appareils idéologiques d'État. In: Positions. Paris: Editions Sociales.

- (2017). A corrente subterrânea do materialismo do encontro. Tradução de Mónica G. Zoppi Fontana. Disponível em: <https:// www.ifch.unicamp.br/criticamarxista/arquivos_biblioteca/ artigo110artigo1.pdf>. Acesso em: 07 jul. 2017.

- (1978). Sustentação de tese em Amiens. Tradução de Rita Lima. In: Posições 1: Rio de Janeiro: Graal..

BALIBAR, Étienne. (1993). L'objet d'Althusser. In: LAZARUS, Sylvain. Politique et Philosophie dans l'ouvre de Louis Althusser. Paris: PUF.

- (1977). Sobre la dictadura del proletariado. Madrid: Siglo XXI.

BOITO JR., Armando. (2016). Indicações para o estudo do marxismo de Althusser. In: PINHEIRO, Jair (Org.). Ler Althusser. Marília: Oficina Universitária; São Paulo: Cultura Acadêmica.

CALDAS, Camilo Onoda. (2015). A teoria da derivação do Estado e do direito. São Paulo: Outras Expressões; Dobra.

DAVOGLIO, Pedro (2018). Althusser e o direito. São Paulo: Ideias \& Letras.

EDElMAN, Bernard. (1976). O Direito Captado pela Fotografia Elementos para uma teoria marxista do direito. Tradução de Soveral Martins e Pires de Carvalho. Coimbra: Centelha. 
GARAUDY, Roger. (1963). A propos des "manuscrits de 1844" de Marx. In: Cahiers du Communisme, mars,.

- (1981). Apelo aos vivos. Tradução de H.P. de Andrade. Rio de Janeiro: Nova Fronteira.

GILlOT, Pascale. (2018). Althusser e a Psicanálise. Tradução de Pedro Eduardo Zini Davoglio (Org.); Fábio Ramos Barbosa Filho; Marie-Lou Lery-Lachaume. São Paulo: Ideias \& Letras.

HIRSCH, Joachim. (2010). Teoria Materialista do Estado. Tradução de Luciano Cavini Matorano. Rio de Janeiro: Revan.

KASHIURA JR., Celso Naoto. (2015). Sujeito de direito e interpelação ideológica: considerações sobre a ideologia jurídica a partir de Pachukanis e Althusser. Revista Direito e Práxis vol. 6, n. 10. Rio de Janeiro: UERJ,.

KASHIURA JR., Celso Naoto; NAVES, Márcio Bilharinho. Pachukanis e a Teoria Geral do Direito e o Marxismo. Revista Jurídica Direito \& Realidade, v. 1, n. 2 (2011). Disponível em: <www. fucamp.edu.br/editora/index.php/direito-realidade/article/ view/245>. Acesso em: 16 nov. 2018.

MAGALHÃES, Juliana Paula (2018). Marxismo, humanismo e direito: Althusser e Garaudy. São Paulo: Ideias \& Letras.

MARX. Karl (2013). O Capital. Tradução de Rubens Enderle. São Paulo: Boitempo Editorial.

- (2011). Grundrisse. Tradução de Mario Duayer e Nélio Schneider. São Paulo: Boitempo.

MASCARO, Alysson Leandro (2018). Filosofia do direito. 6.ed. São Paulo, Atlas.

- (2018). Crise e Golpe. São Paulo: Boitempo.

- (2015). Introdução ao Estudo do Direito. 5. ed. São Paulo: Atlas.

- (2013). Estado e forma política. São Paulo: Boitempo.

MOTTA, Luiz Eduardo. (2014). A favor de Althusser - revolução e ruptura na teoria marxista. Rio de Janeiro: FAPERJ.

NAVES, Márcio Bilharinho (2013). Marxismo e direito: um estudo sobre Pachukanis. São Paulo: Boitempo.

- (2008). Marx - Ciência e Revolução. São Paulo: Quartier Latin.

- (2014). A questão do direito em Marx. São Paulo: Outras Expressões; Dobra. 
PACHUKANIS, Evguiéni (2017). Teoria Geral do Direito e Marxismo. Tradução de Paula Vaz de Almeida. São Paulo: Boitempo.

- (2009). A teoria marxista do direito e a construção do socialismo. In: NAVES, Márcio Bilharinho (Org). O discreto charme do direito burguês: ensaios sobre Pachukanis. Campinas: IFCH-UNICAMP.

THÉVENIN, Nicole-Edith. (1977). Révisionnisme et philosophie de l'aliénation. Paris: Christian Bourgois.

TURCHETTO, Maria (2005). As características específicas da transição ao comunismo. Tradução de Márcio Bilharinho Naves. In: NAVES, Márcio Bilharinho. Análise Marxista e Sociedade de Transição. Campinas: UNICAMP.

VILLEY, Michel. (2001). Philosophie du droit. Définitions et fins du droit. Le moyens du droit. Paris: Dalloz. 